\title{
ANALISIS DAN PERANCANGAN SISTEM INFORMASI ENERGI NUKLIR
}

\author{
Yohanes Dwi Anggoro, Sriyana, Arief Tris Yuliyanto, Wiku Lulus Widodo \\ Pusat Kajian Sistem Energi Nuklir (PKSEN) \\ Badan Tenaga Nuklir Nasional \\ Jl. Kuningan Barat, Mampang Prapatan, Jakarta Selatan 12710 \\ Telp./Fax.: 021-5204243, Email:yohanes.anggoro@batan.go.id
}

\begin{tabular}{|c|c|c|}
\hline Diterima & Diterima dalam bentuk revisi & Disetujui \\
\hline 02 Maret 2015 & 04 Mei 2015 & 18 Mei 2015 \\
\hline
\end{tabular}

\begin{abstract}
ABSTRAK
ANALISIS DAN PERANCANGAN SISTEM INFORMASI ENERGI NUKLIR. Pengelolaan hasil penelitian dan kegiatan Pusat Kajian Sistem Energi Nuklir (PKSEN), baik dalam bentuk dokumen maupun hasil kegiatan lainnya, merupakan bagian yang penting dari rangkaian kegiatan pencapaian Misi PKSEN. Pengelolaan dokumen yang baik akan memudahkan pemberian masukan perbaikan ataupun penggunaan hasil yang maksimal. Namun selama beberapa tahun belakangan ini, masih terdapat beberapa kekurangan di dalam pengelolaan dokumen hasil penelitian dan kegiatan yang dilakukan PKSEN. Tujuan dari penelitian ini adalah melakukan analisis dan perancangan konsep flow desain/layout Sistem Informasi Energi Nuklir untuk mempermudah penerapan Sistem Informasi Energi Nuklir (SIEN). Sistem informasi ini, disamping digunakan sebagai sistem pengelolaan hasil penelitian dan kegiatan PKSEN juga dapat digunakan sebagai media informasi bagi masyarakat. Paket Sistem Informasi Energi Nuklir ini diharapkan menjadi "satu pintu gerbang" informasi PKSEN. Metodologi penelitian yang digunakan adalah: (i) analisis sistem organisasi, (ii) analisis dan perancangan sistem informasi; (iii) analisis dan perancangan sistem perangkat lunak; (iv) analisis dan perancangan sistem basis data. Pada penelitian ini telah: diidentifikasi seluruh aktivitas dan sumberdaya organisasi PKSEN, dilakukan analisis penerapan SIEN menggunakan analisis SWOT, diidentifikasi beberapa jenis perangkat yang dibutuhkan, disusun hirarki SIEN, ditentukan sistem basis data yang digunakan adalah sistem basis data terpusat dan telah ditentukan pemilihan DBMS menggunakan MySQL. Hasil yang diperoleh adalah sebuah rancangan dasar Sistem Informasi Energi Nuklir (SIEN) yang nantinya akan mempermudah penerapan SIEN yang akan digunakan sebagai sistem pengelolaan hasil penelitian dan kegiatan PKSEN juga dapat digunakan sebagai media informasi bagi masyarakat.

Kata kunci: analisis, perancangan, sistem informasi, energi nuklir.
\end{abstract}

\begin{abstract}
ANALYSIS AND DESIGN OF NUCLEAR ENERGY INFORMATION SYSTEMS. Management of research reports and activities of the Center for Nuclear Energy System Assessment (PKSEN), either in the form of documents and the results of other activities, are important part of the series of activities PKSEN mission achievement. Management of good documents will facilitate the provision of improved inputs or use the maximum results. But over the past few years, there are still some problem in the management of research reports and activities performed by PKSEN. The purpose of this study is to analyze and design flow layout of the Nuclear Energy Information System to facilitate the implementation of the Nuclear Energy Information System. In addition to be used as a research management system and PKSEN activities, it can also be used as a information media for the community. Nuclear Energy Information System package is expected to be "one gate system" for PKSEN information. The research methodology used are: (i) analysis of organizational systems, (ii) the analysis and design of information systems; (iii) the analysis and design of software systems; (iv) the analysis and design of database systems. The results of this study are: had identified and resources throughout the organization PKSEN activation, had analyzed the application of SIEN using SWOT analysis, had identified several types of devices required, had been compiled hierarchy of SIEN, had determined that the database system used is a centralized database system and had elections MySQL as DBMS. The result is a basic design of the Nuclear Energy Information System) which will used as a research and activities management system of PKSEN and also can be used as a medium of information for the community.
\end{abstract}

Keywords: analysis, design, information systems, nuclear energy. 


\section{PENDAHULUAN}

Energi nuklir adalah sumber energi potensial, berteknologi tinggi, berkeselamatan handal, ekonomis, dan berwawasan lingkungan. Oleh karena itu, energi nuklir merupakan sumber energi yang layak dipertimbangkan dalam perencanaan energi jangka panjang guna mendukung pembangunan berkelanjutan. Mengingat situasi penyediaan (supply) energi yang semakin tidak seimbang dengan kebutuhannya (demand), maka opsi nuklir dalam perencanaan sistem energi nasional jangka panjang merupakan suatu solusi yang perlu dipertimbangkan. Sesuai Peraturan Presiden No. 5 Tahun 2006, bahwa pangsa energi nuklir sampai tahun 2025 mencapai kurang lebih $2 \%$ dari energi final.

BATAN (Badan Tenaga Nuklir Nasional) sebagai lembaga pemerintah, berdasarkan Undangundang No. 10 Tahun 1997 tentang Ketenaganukliran, akan terus bekerja sama dengan lembaga pemerintah terkait, lembaga swadaya masyarakat, lembaga dan masyarakat internasional untuk mengembangkan energi nuklir di Indonesia. Sesuai dengan SK Kepala BATAN No. 123/KA/VIII/2007, PPEN (Pusat Pengembangan Energi Nuklir) yang kemudian pada awal tahun 2014 berubah nama menjadi Pusat Kajian Sistem Energi Nuklir (PKSEN) mempunyai tugas melaksanakan pengembangan di bidang energi nuklir. Implementasi dari tugas dan fungsi PKSEN adalah pelaksanaan program kegiatan yang sesuai dengan rencana strategis yang telah dicanangkan.

Pengelolaan hasil penelitian dan kegiatan PKSEN, baik dalam bentuk dokumen maupun hasil kegiatan lainnya, merupakan bagian yang penting dari rangkaian kegiatan pencapaian Misi PKSEN. Pengelolaan hasil yang baik akan memudahkan pemberian masukan perbaikan ataupun penggunaan hasil yang maksimal. Namun selama beberapa tahun belakangan ini, masih terdapat beberapa kekurangan, terutama di dalam pengelolaan dokumen hasil penelitian dan kegiatan yang dilakukan PKSEN, oleh karena itu untuk mengelola dan menyimpan seluruh data ataupun dokumen tersebut, dapat memanfaatkan teknologi informasi. Seiring dengan berjalannya waktu dan perkembangan teknologi informasi, agar pengelolaan data hasil penelitian dan kegiatan PKSEN dapat dengan mudah disimpan, diakses dan dimanfaatkan secara efektif dan efisien, maka perlu dibuat Sistem Informasi Energi Nuklir ini. Manfaat yang diharapkan adalah preservasi iptek di PKSEN dapat dilakukan dengan baik. Dengan demikian aspek pelayanan terhadap pelanggan, dalam hal ini pengguna data/informasi dan juga termasuk pemangku kepentingan, diharapkan akan lebih baik.

Tujuan dari penelitian ini adalah melakukan analisis dan perancangan konsep flow desain/layout Sistem Informasi Energi Nuklir untuk mempermudah penerapan Sistem Informasi Energi Nuklir (SIEN). Sistem informasi ini, disamping digunakan sebagai sistem pengelolaan hasil penelitian dan kegiatan PKSEN juga dapat digunakan sebagai media informasi bagi masyarakat. Paket Sistem Informasi Energi Nuklir ini diharapkan menjadi "satu pintu gerbang " informasi PKEN. Sistem ini nantinya akan terdiri dari komponen sistem perangkat lunak (software) dan perangkat keras (hardware).

\section{METODE PENELITIAN}

Gambar 1 berikut menunjukkan tahapan Analisis dan Perancangan Sistem Informasi (ASPI), yang dibagi menjadi empat (4) tahapan proses, yaitu:

a. Analisis Sistem Organisasi, bertujuan untuk:

- Mengidentifikasi core business dari organisasi.

- Mengidentifikasi aktivitas yang mengelola core business.

- Mengidentifikasi resources utama dari core business tersebut.

- Mengidentifikasi konteks dari sistem informasi yang mendukung pengelolaan aktivitas, resources utama maupun core business.

- Mengidentifikasi kebutuhan informasi bagi perancangan Sistem informasi.

b. Analisis dan Perancangan Sistem Informasi, bertujuan untuk:

- Membangun arsitektur sistem informasi.

- Mengidentifikasi konteks Sistem Perangkat Lunak dan Sistem Basis Data.

- Mengidentifikasi konteks dan spesifikasi elemen lainnya (Sistem Perangkat Keras, Sistem

- Jaringan Komputer, dll). 
- Mengidentifikasi entitas data yang relevan dari calon Sistem Basis Data.

c. Analisis dan Perancangan Sistem Perangkat Lunak, bertujuan untuk merancang konsep dasar Sistem Perangkat Lunak.

d. Analisis dan Perancangan Sistem Basis Data, bertujuan untuk membangun Sistem Basis Data yang terpusat ataupun yang tersebar.

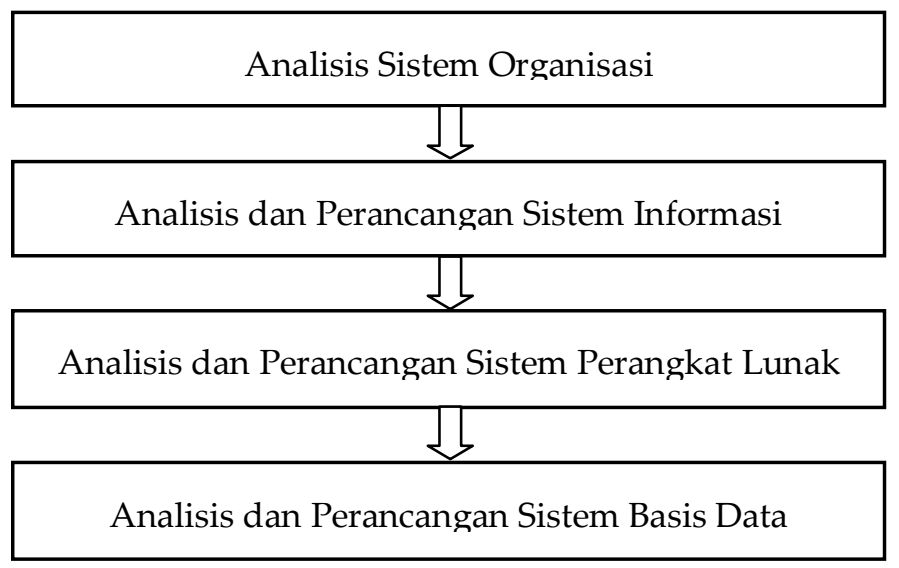

Gambar 1. Tahapan analisis dan perancangan sistem informasi.

\section{KONSEP DASAR SISTEM INFORMASI}

\subsection{Konsep Dasar Sistem}

Suatu sistem pada dasarnya adalah sekolompok unsur yang erat hubungannya satu dengan yang lain, yang berfungsi bersama sama untuk mencapai tujuan tertentu. Secara sederhana, suatu sistem dapat diartikan sebagai suatu kumpulan atau himpunan dari unsur, komponen, atau variabel yang terorganisir, saling berinteraksi, saling tergantung satu sama lain, dan terpadu. Dari definisi ini dapat dirinci lebih lanjut pengertian sistem secara umum, yaitu[1]:

- Setiap sistem terdiri dari unsur unsur.

- Unsur-unsur tersebut merupakan bagian terpadu sistem yang bersangkutan.

- Unsur sistem tersebut bekerja sama untuk mencapai tujuan sistem.

- Suatu sistem merupakan bagian dari sistem lain yang lebih besar.

\subsection{Konsep Dasar Informasi}

Secara umum informasi dapat didefinisikan sebagai hasil dari pengolahan data dalam suatu bentuk yang lebih berguna dan lebih berarti bagi penerimanya yang menggambarkan suatu kejadian kejadian yang nyata yang digunakan untuk pengambilan keputusan. Informasi merupakan data yang telah diklasifikasikan atau diolah atau diinterpretasi untuk digunakan dalam proses pengabilan keputusan $^{[1]}$

Data dibedakan menjadi tiga (3) jenis, yaitu (i) Data operasional, berupa data yang disimpan didalam database, (ii) Data masukan (input data), data dimasukan melalui peralatan input (keyboard) yang dapat merubah menjadi data operasional, dan (iii) Data keluaran (output data), merupakan hasil dari dalam sistem yang mengakses data operasional. Data memiliki ciri-ciri seperti dibawah ini[2]:

- Data disimpan secara terintegrasi (integrated), database merupakan kumpulan berbagai macam file dari aplikasi-aplikasi yang berbeda dan disusun dengan cara menghilangkan bagian-bagian yang rangkap (redundant)

- Data dapat dipakai secara bersama-sama (shared), dimana masing-masing bagian dari database dapat diakses oleh pemakai dalam waktu yang bersamaan dan dapat digunakan juga untuk aplikasi yang berbeda.

\subsection{Konsep Dasar Sistem Informasi}

Sistem informasi adalah suatu sistem dalam suatu organisasi yang mempertemukan kebutuhan pengolahan transaksi harian yang mendukung fungsi operasi organisasi yang bersifat 
manajerial dengan kegiatan strategi dari suatu organisasi untuk dapat menyediakan kepada pihak luar tertentu dengan informasi yang diperlukan untuk pengambilan keputusan. Sistem informasi dalam suatu organisasi dapat dikatakan sebagai suatu sistem yang menyediakan informasi bagi semua tingkatan dalam organisasi tersebut kapan saja diperlukan. Sistem ini menyimpan, mengambil, mengubah, mengolah dan mengkomunikasikan informasi yang diterima dengan menggunakan sistem informasi atau peralatan sistem lainnya ${ }^{[1]}$.

Sistem informasi terdiri dari komponen komponen yang disebut blok bangunan (building blok), yang terdiri dari komponen input, komponen model, komponen output, komponen teknologi, komponen hardware, komponen software, komponen basis data, dan komponen kontrol. Semua komponen tersebut saling berinteraksi satu dengan yang lain membentuk suatu kesatuan untuk mencapai sasaran ${ }^{[3]}$.

- Komponen input. Input mewakili data yang masuk kedalam sistem informasi. Input disini termasuk metode dan media untuk menangkap data yang akan dimasukkan, yang dapat berupa dokumen dokumen dasar.

- Komponen model. Komponen ini terdiri dari kombinasi prosedur, logika, dan model matematik yang akan memanipulasi data input dan data yang tersimpan di basis data dengan cara yang sudah ditentukan untuk menghasilkan keluaran yang diinginkan.

- Komponen output. Hasil dari sistem informasi adalah keluaran yang merupakan informasi yang berkualitas dan dokumentasi yang berguna untuk semua pemakai sistem.

- Komponen teknologi. Teknologi merupakan "tool box" dalam sistem informasi, Teknologi digunakan untuk menerima input, menjalankan model, menyimpan dan mengakses data, menghasilkan dan mengirimkan keluaran, dan membantu pengendalian dari sistem secara keseluruhan.

- Komponen hardware. Hardware berperan penting sebagai suatu media penyimpanan vital bagi sistem informasi, yang berfungsi sebagai tempat untuk menampung database atau lebih mudah dikatakan sebagai sumber data dan informasi untuk memperlancar dan mempermudah kerja dari sistem informasi.

- Komponen software. Software berfungsi sebagai tempat untuk mengolah, menghitung dan memanipulasi data yang diambil dari hardware untuk menciptakan suatu informasi.

- Komponen basis data. Basis data (database) merupakan kumpulan data yang saling berkaitan dan berhubungan satu dengan yang lain, tersimpan di pernagkat keras komputer dan menggunakan perangkat lunak untuk memanipulasinya. Data perlu disimpan dalam basis data untuk keperluan penyediaan informasi lebih lanjut. Data di dalam basis data perlu diorganisasikan sedemikian rupa supaya informasi yang dihasilkan berkualitas. Organisasi basis data yang baik juga berguna untuk efisiensi kapasitas penyimpanannya. Basis data diakses atau dimanipulasi menggunakan perangkat lunak

\section{INFRASTRUKTUR TEKNOLOGI INFORMASI}

\subsection{Suprastruktur}

Sebuah program aplikasi yang baik tidak hanya menterjemahkan proses manual ke dalam sistem dalam bentuk medianya tetapi meliputi proses yang terdapat didalamnya dengan memberikan kemudahan bagi penggunanya dan tentu saja memberikan nilai tambah bagi perkembangan suatu organisasi. Perubahan proses akan mengubah SOP (Standard Operasional Procedure) yang sudah ada, dan tentu saja akan melibatkan orang-orang yang ada didalamnya. Sistem informasi merupakan aplikasi komputer untuk mendukung operasi dari suatu organisasi, seperti operasi, instalasi, perawatan komputer, software, dan data. Secara teknis sistem informasi dapat didefinisikan sebagai sekumpulan komponen yang saling berhubungan mengumpulkan, memproses, menyimpan dan mendistribusikan informasi untuk menunjang pengawasan dan pengambilan keputusan dalam suatu organisasi. Manajemen tidak dapat mengabaikan sistem informasi karena sistem informasi memainkan peran yang kritikal di dalam organisasi. Sistem informasi ini sangat mempengaruhi secara langsung bagaimana manajemen mengambil keputusan, membuat rencana, dan mengelola para pegawainya, serta meningkatkan sasaran kinerja yang hendak dicapai, yaitu 
bagaimana menetapkan ukuran atau bobot setiap tujuan atau kegiatan, menetapkan standar pelayanan minimum, dan bagaimana menetapkan standar dan prosedur pelayanan baku kepada masyarakat. Oleh karenanya, tanggung jawab terhadap sistem informasi tidak dapat didelegasikan begitu saja kepada sembarang pengambil keputusan ${ }^{[4]}$.

Semakin meningkat saling ketergantungan antara rencana strategis instansi, peraturan dan prosedur di satu sisi dengan sistem informasi (software, hardware, database, dan telekomunikasi) di sisi yang lainnya. Perubahan di satu komponen akan mempengaruhi komponen lainnya. Hubungan ini menjadi sangat kritikal manakala manajemen ingin membuat rencana ke depan. Aktivitas apa yang akan dilakukan lima tahun ke depan biasanya juga sangat tergantung kepada sistem apa yang tersedia untuk dapat dilaksanakan. Sebagai contoh, peningkatan produktivitas kerja para pegawai sangat tergantung pada jenis dan kualitas dari sistem informasi organisasi. Perubahan lain dalam hubungan sistem informasi dengan organisasi adalah semakin meningkatnya cakupan dan ruang lingkup dari sistem informasi dan aplikasinya. Pengembangan dan pengelolaan sistem dewasa ini membutuhkan keterlibatan banyak pihak di dalam organisasi, jika dibandingkan peran dan keterlibatanya pada periode-periode yang lalu. Sebagaimana sudah disampaikan dengan meningkatnya kecenderungan organisasi berteknologi digital, maka sistem informasi di dalam organisasi dapat meliputi jangkauan yang semakin luas hingga kepada masyarakat, instansi pemerintahan lainnya, dan bahkan informasi mengenai perkembangan politik terakhir[5].

Infrastruktur e-Government yang baik akan melibatkan beberapa aspek, yaitu[i]:

- Kepemimpinan manajemen (leadership)

Peran dan dukungan pimpinan dalam pemanfaatan teknologi informasi untuk pengelolaan dokumen hasil kegiatan dan penelitian sangatlah besar. Penerapan suatu kepemimpinan juga membawa misi positif dan dinamis tertentu, yang kalau perlu harus dapat mengubah situasi dan kondisi yang dinilai menjadi penghambat bagi kemajuan, efektivitas dan efisiensi[7].

Kondisi optimum dapat dicapai jika memang ada perhatian khusus dari pimpinan dalam rangka pendayagunaan teknologi informasi untuk pengelolaan dokumen hasil kegiatan dan penelitian.

- Sumberdaya Manusia

Infrastruktur Sumberdaya Manusia menjadi subyek dan obyek pemanfaatan teknologi informasi untuk Sistem Informasi Energi Nuklir (SIEN). Tingkat pendidikan yang baik seharusnya tidak menjadi kendala dalam pengembangan SIEN, terlebih lagi jika ada upaya konstruksional dari seluruh pihak seperti program pendampingan, pembinaan, dan pelatihan.

- Regulasi dan Kebijakan

Pedoman dan aturan pendayagunaan teknologi informasi mutlak diperlukan untuk menjamin pelaksanaan dan pemanfaatan teknologi informasi sesuai dengan tujuan yang ingin dicapai. Kebijakan yang tepat guna dan tepat sasaran dapat mengakselerasi penyebaran informasi hasil kegiatan dan penelitian melalui pemanfaatan teknologi informasi.

\subsection{Infrastruktur Jaringan}

Infrastruktur jaringan terdiri dari 3 (tiga) komponen utama, yaitu:

- Local Area Network (LAN) dan Wide Area Network (WAN)

Gabungan lebih dari dua unit komputer yang terintegrasi dalam satu sistem jaringan komputer biasa disebut Local Area Network (LAN). Sedangkan gabungan dari beberapa jaringan komputer yang terhubung meliputi cakupan area yang luas disebut Wide Area Network (WAN).

Manfaat dari penggunaan LAN dan WAN ini yaitu ${ }^{[8]}$ :

a. Memfasilitasi sharing data dan informasi.

b. Memfasilitasi proses komunikasi antar sesama user dalam jaringan.

c. Memfasilitasi fungsi distribusi dan pengelolaan data dan informasi.

d. Memudahkan manajemen pengalokasian sumberdaya jaringan.

e. Memaksimalkan kinerja user dengan biaya yang seminimal mungkin.

- Teknologi Keamanan Jaringan 
LAN atau WAN yang tidak diperhatikan faktor keamanannya akan sangat rentan terhadap gangguan yang dapat merusak data dan informasi serta hardware dalam jaringan tersebut. Untuk itu, dalam membangun infrastruktur teknologi informasi, faktor keamanan jaringan adalah hal yang sangat penting. Network security therefore needs to guard networked computer systems and protect electronic data that is either stored 10 networked computers or transmitted to the networks $[9]$.

- Server

Server merupakan sebuah hardware yang dapat memfasilitasi kinerja jaringan dan juga dapat menjadi database utama untuk penyimpanan data dan informasi.

\subsection{Infrastruktur Informasi}

Infrastruktur informasi terdiri dari 4 (empat) komponen utama, yaitu[6]:

- Standardisasi struktur dan format data.

Dalam konsep integrasi sistem informasi melalui teknologi informasi diperlukan standardisasi struktur dan format data untuk memudahkan proses sinkronisasi, entri dan updating data dan informasi.

- Metode Pembagian Data (Sharing Data).

Pembagian data perlu dipertimbangkan karena jenis-jenis dari data dan informasi pun bermacam-macam. Pada umumnya data dan informasi merupakan konsumsi publik, namun ada juga beberapa jenis data dan informasi yang hanya bisa diakses dalam sementara waktu oleh kalangankalangan tertentu, biasanya kalangan pimpinan atau pihak intelejen.

- Database Security.

Sama halnya dengan faktor keamanan jaringan, database yang berfungsi sebagai aplikasi penyimpan data dan informasi perlu diperhatikan keamanannya agar aman dari gangguangangguan yang dapat merusak data dan informasi tersebut.

- Pengembangan Metadata.

Metadata sangat diperlukan oleh para user atau pengakses data dan informasi karena dapat memberikan informasi tambahan dari data dan informasi yang diperoleh.

\subsection{Infrastruktur Aplikasi}

Infrastruktur aplikasi terdiri dari 2 (dua) komponen utama, yaitu[6]:

- Aplikasi Website.

Website merupakan suatu wujud pemanfaatan teknologi informasi yang dapat memvisualisasikan keberadaan suatu instansi atau organisasi dengan mengikutsertakan fiturfitur aplikasi didalamnya sehingga dapat melayani publik dalam konteks yang lebih luas lagi.

- Aplikasi Offline Berbasis Jaringan.

Aplikasi offline berbasis jaringan biasanya digunakan secara intern instansi atau organisasi. Aplikasi-aplikasi ini biasanya dibangun untuk menerapkan e-Office. Tujuannya untuk mengefisiensikan beberapa faktor yang mendukung kinerja suatu instansi atau organisasi.

\section{HASIL DAN PEMBAHASAN}

\subsection{Analisis Sistem Organisasi}

Pada tahap analisis sistem organisasi ini, telah dilakukan proses pengumpulan data dan analisis kebutuhan data yang terkait dengan struktur dan tugas serta tanggung jawab dari organisasi Pusat Kajian Sistem Energi Nuklir (PKSEN). Hal tersebut perlu dilakukan karena Sistem Informasi Energi Nuklir (SIEN) nantinya harus dapat mencerminkan dan mendeskripsikan secara lengkap tugas dan tanggung PKSEN. Berdasarkan Peraturan Kepala BATAN No. 14 Tahun 2013, PKSEN memiliki struktur organisasi seperti terlihat pada Gambar 2. 


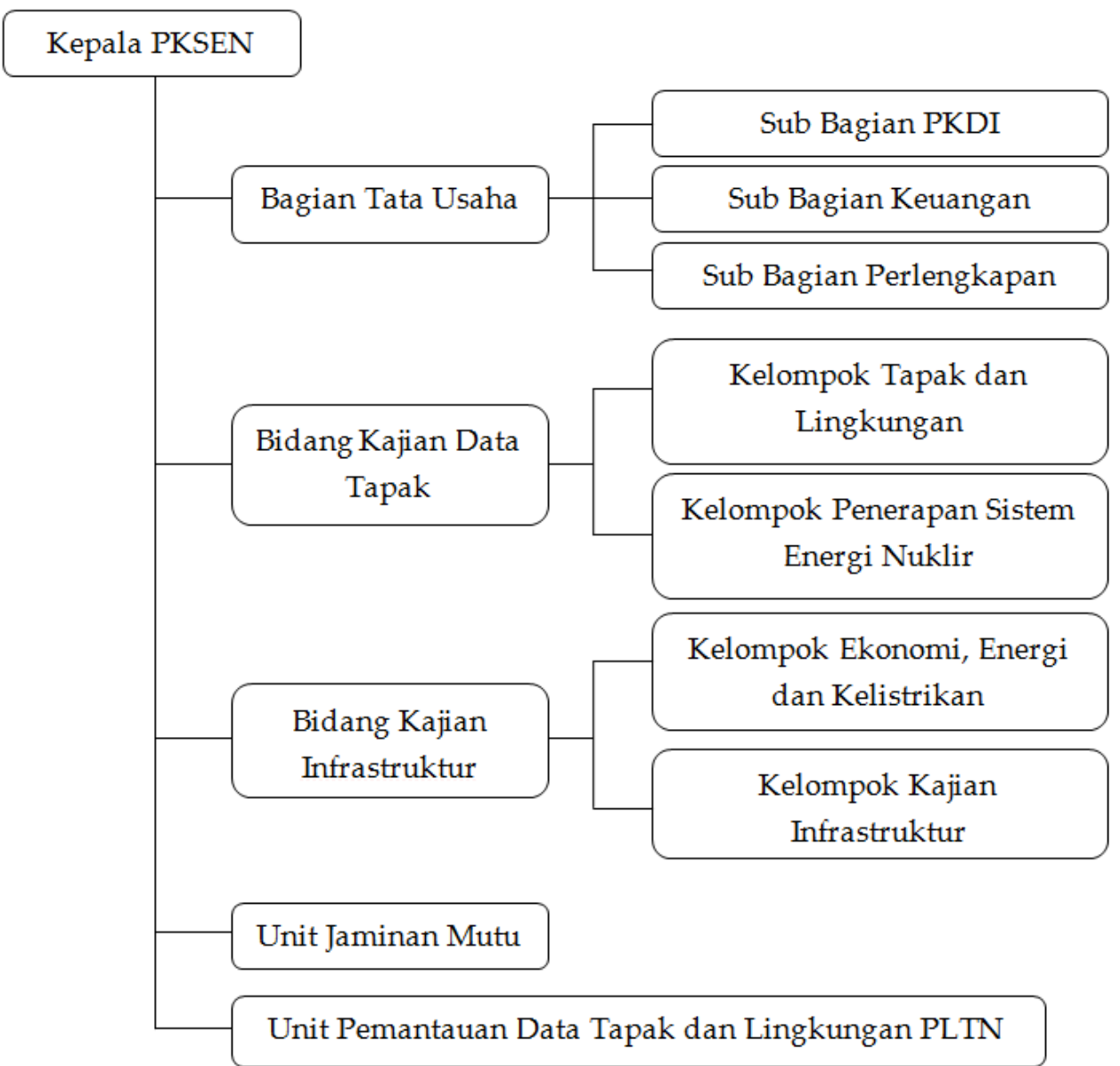

Gambar 2. Struktur Organisasi PKSEN.

Menurut Peraturan Kepala BATAN No. 14 Tahun 2013, Pusat Kajian Sistem Energi Nuklir (PKSEN) mempunyai tugas melaksanakan perumusan dan pengendalian kebijakan teknis, pelaksanaan, dan pembinaan dan bimbingan di bidang pengkajian sistem energi nuklir. Secara teknis, kegiatan pengkajian sistem energi nuklir dilakukan oleh Bidang Kajian Data Tapak, Bidang Kajian Infrastruktur dan Unit Pemantauan Data dan Lingkungan PLTN. Bidang Kajian Data Tapak mempunyai tugas melaksanakan pengkajian data tapak dan penerapan sistem energi nuklir, Bidang Kajian Infrastruktur mempunyai tugas melaksanakan pengkajian dan dukungan teknis persiapan infrastruktur sistem energi nuklir, dan Unit Pemantauan Data Tapak dan Lingkungan PLTN mempunyai tugas melaksanakan pemantauan data lingkungan, oceanografi, geografi, sosial dll yang sifat datanya dinamis dan dipantau untuk mendapatkan tren dan data terkini. Sedangkan secara administrasi, seluruh kegiatan PKSEN didukung oleh Bagian Tata Usaha dan Unit Jaminan Mutu. Bagian Tata Usaha mempunyai tugas melaksanakan urusan perencanaan, persuratan dan kearsipan, kepegawaian, keuangan, perlengkapan dan rumah tangga, dokumentasi ilmiah dan publikasi serta pelaporan. Unit Jaminan Mutu mempunyai tugas melakukan pengembangan, pemantauan pelaksanaan dan audit internal sistem manajemen mutu pengkajian sistem energi nuklir.

Seiring dengan berjalannya waktu dan perkembangan teknologi informasi, supaya pengelolaan data hasil penelitian dan kegiatan PKSEN dapat dengan mudah disimpan, diakses dan dimanfaatkan secara efektif dan efisien, maka perlu dibuat Sistem Informasi Energi Nuklir (SIEN). Manfaat yang diharapkan adalah preservasi hasil kegiatan penelitan dan pengkajian di PKSEN dapat dilakukan dengan baik. Dengan demikian aspek pelayanan terhadap pelanggan, dalam hal ini pengguna data/informasi dan juga termasuk pemangku kepentingan, diharapkan akan lebih baik. Selain itu SIEN dapat digunakan sebagai media informasi bagi masyarakat. Sehingga dapat dikatakan bahwa SIEN merupakan pintu gerbang utama untuk memperoleh seluruh informasi kegiatan penelitian dan pengkajian PKSEN. 


\subsection{Analisis dan Perancangan Sistem Informasi}

Analisis pemanfaatan Sistem Informasi (SI) untuk pengelolaan data dan hasil kegiatan penelitian dan pengkajian dilakukan dengan menggunakan Analisis SWOT. Hasil dari Analisis SWOT tersebut terlihat pada Tabel 1 berikut.

Tabel 1. Analisis Pemanfaatan Sistem Informasi (SI) menggunakan Analisis SWOT

\begin{tabular}{|c|c|}
\hline STRENGTHS & WEA \\
\hline $\begin{array}{l}\text { - Kepala PKSEN memiliki komitmen yang kuat } \\
\text { terhadap pembuatan dan perancangan SIEN. } \\
\text { - } \text { Kegiatan penelitian dan pengkajian PKSEN } \\
\text { memiliki posisi nasional yang strategis. } \\
\text { - SIEN berperan sebagai penyambung } \\
\text { diseminasi kegiatan penelitian dan pengkajian } \\
\text { sistem energi nuklir ke masyarakat. } \\
\text { - SIEN sebagai pangkalan data seluruh data } \\
\text { hasil penelitian dan pengkajian sistem energi } \\
\text { nuklir. }\end{array}$ & $\begin{array}{l}\text { - } \text { Budaya berbagi informasi masih lemah. } \\
\text { - Masih ada istilah "Rahasia" untuk beberapa } \\
\text { data yang memang cukup beresiko apabila } \\
\text { diketahui oleh masyarakat umum. } \\
\text { - SI masih merupakan "makhluk yang aneh" } \\
\text { bagi sebagian peneliti di PKSEN. } \\
\text { - } \text { Keterbatasan SDM di bidang teknik } \\
\text { informatika. } \\
\text { - Keterbatasan biaya pengadaan SI. }\end{array}$ \\
\hline OPPC & THREATS \\
\hline $\begin{array}{l}\text { - } \text { Adanya dukungan dari satuan kerja yang lain } \\
\text { (PPIKSN). } \\
\text { - } \text { Membudayakan sharing information, } \\
\text { dokumentasi, pengarsipan yang baik. } \\
\text { - } \\
\text { Membina dan melatih seluruh pihak (peneliti, } \\
\text { masyarakat dll) untuk memberdayakan SI. } \\
\text { - } \\
\text { - } \\
\text { Membangun infrastruktur yang memadai. }\end{array}$ & 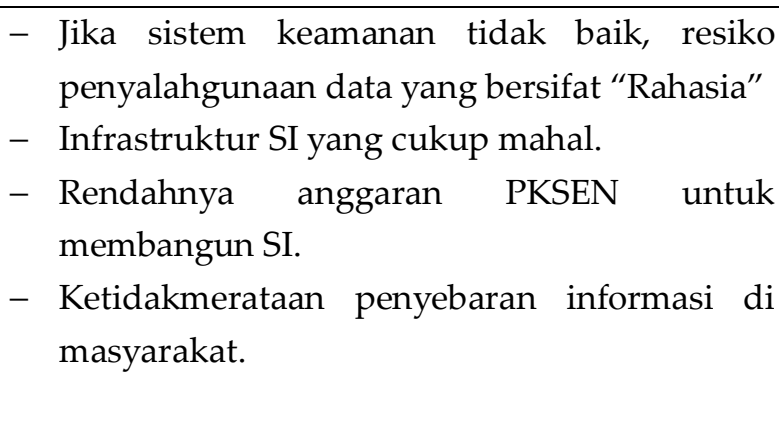 \\
\hline
\end{tabular}

Dari analisis SWOT tersebut, terlihat bahwa terdapat beberapa kelemahan dan permasalahan yang apabila tidak diambil tindakan preventif dan aktuatif, permasalahan tersebut dapat menjadi ancaman yang akan menghambat proses diseminasi hasil kegiatan penelitian dan pengkajian di bidang sistem energi nuklir. Oleh karena itu, untuk mengatasi permasalahan dan ancaman tersebut serta dengan adanya beberapa kekuatan dan peluang, pemanfaatan teknologi sistem informasi sangat mungkin dilakukan dan Sistem Informasi Energi Nuklir merupakan salah satu bentuk terobosan yang dapat meningkatkan akses informasi dan proses komunikasi.

Untuk membangun Sistem Informasi Energi Nuklir yang baik, sangat diperlukan beberapa perangkat keras, perangkat lunak, dan perangkat jaringan. Tabel 2 berikut menunjukkan kebutuhan beberapa perangkat keras dan perangkat lunak yang diperlukan sekaligus dengan rekomendasi spesifikasinya. 
Tabel 2. Jenis perangkat yang dibutuhkan.

\begin{tabular}{|c|c|c|}
\hline Jenis Perangkat & Spesifikasi & Fungsi \\
\hline \multicolumn{3}{|l|}{ PERANGKAT KERAS } \\
\hline Komputer server & HP ProLiant ML350G6-869 & $\begin{array}{l}\text { Server utama SIEN dan } \\
\text { database. }\end{array}$ \\
\hline Komputer client & HP Touchsmart 520-1135D All-in-One & Akses langsung user ke SIEN \\
\hline Harddisk eksternal & $\begin{array}{l}\text { WESTERN DIGITAL My Passport } \\
\text { Essential USB 3.0 2TB 2.5" }\end{array}$ & Backup data \\
\hline \multicolumn{3}{|l|}{ PERANGKAT LUNAK } \\
\hline Sistem operasi & $\begin{array}{l}\text { MICROSOFT Windows Web Server } \\
2008\end{array}$ & Sistem utama server \\
\hline Antivirus & Norton Symantec & $\begin{array}{l}\text { Mencegah serangan virus } \\
\text { komputer }\end{array}$ \\
\hline Web design & ADOBE CS 6 & Mendesain tampilan SIEN \\
\hline Software GIS & Arc GIS & $\begin{array}{l}\text { Salah satu aplikasi SIEN untuk } \\
\text { pengolahan citra / pemetaan. }\end{array}$ \\
\hline \multicolumn{3}{|l|}{ PERANGKAT JARINGAN } \\
\hline Ethernet Switch & HP 1810-8G v2 Switch [J9802A] & $\begin{array}{l}\text { Menghubungkan server ke } \\
\text { jaringan utama. }\end{array}$ \\
\hline Wireless network & $\begin{array}{l}\text { CISCO Linksys Wireless-N ADSL2+ } \\
\text { Modem Router [X3000-AP] }\end{array}$ & $\begin{array}{l}\text { Menghubungkan antara server } \\
\text { dengan client. }\end{array}$ \\
\hline Kabel dan konektor data & Kabel Belden Cat 5 dan konektor RJ45 & $\begin{array}{l}\text { Menghubungkan Ethernet } \\
\text { switch dan wireless network }\end{array}$ \\
\hline
\end{tabular}

\subsection{Analisis dan Perancangan Sistem Perangkat Lunak}

Pada tahap analisis dan perancangan sistem perangkat lunak, telah dilakukan perancangan hirarki Sistem Informasi Enrgi Nuklir yang sudah disesuaikan dengan kebutuhan organisasi Pusat Kajian Sistem Energi Nuklir (PKSEN) seperti yang telah dijelaskan sebelumnya pada sub.bab 5.1. Gambar 3 berikut menunjukkan hirarki dari SIEN.

\subsection{Analisis dan Perancangan Sistem Basis Data}

Pada tahap analisis dan perancangan sistem basis data telah ditentukan bahwa sistem basis data yang akan digunakan pada aplikasi Sistem Informasi Energi Nuklir (SIEN) ini adalah sistem basis data yang terpusat, artinya bahwa seluruh data yang terkait dengan hasil dan kegiatan Pusat Kajian Sistem Energi Nuklir (PKSEN) akan tersimpan menjadi satu kesatuan di dalam komputer server. Oleh karena itu diperlukan sebuah komputer server yang memiliki kapasitas penyimpanan data yang sangat besar (minimal 2 Terabyte) dan didukung oleh sistem jaringan yang handal, karena nantinya komputer server ini akan menjadi pusat data yang akan diakses oleh seluruh user melalui jaringan internet.

Secara umum pengertian Database Management System (DBMS) adalah merupakan perangkat lunak (software) yang mampu menangani seluruh akses pada database untuk melayani kebutuhan pengguna. Saat ini terdapat beberapa perangkat lunak DBMS yang sering digunakan dalam aplikasi program antara lain: MySQL, ORACLE, FIREBIRD, Microsoft SQL Server 2000, Visual Foxpro, Database Desktop Paradox dan lain sebagainya. Masing-masing perangkat lunak DBMS tersebut memiliki beberapa kelemahan dan kelebihan yang berbeda satu dengan yang lain. Pemilihan DBMS yang baik harus memperhatikan beberapa faktor seperti faktor teknis, ekonomi dan beberapa faktor pendukung lainnya.

Pada perancangan Sistem Informasi Energi Nuklir (SIEN) kali ini pemilihan DBMS lebih berfokus ke MySQL, hal ini dikarenakan beberapa hal, antara lain: free (bebas didownload), stabil dan tangguh, fleksibel dengan berbagai pemrograman, memiliki keamanan yang baik, adanya dukungan dari banyak komunitas, memiliki kemudahan dalam mengatur database,dan perkembangan software yang cukup cepat. 


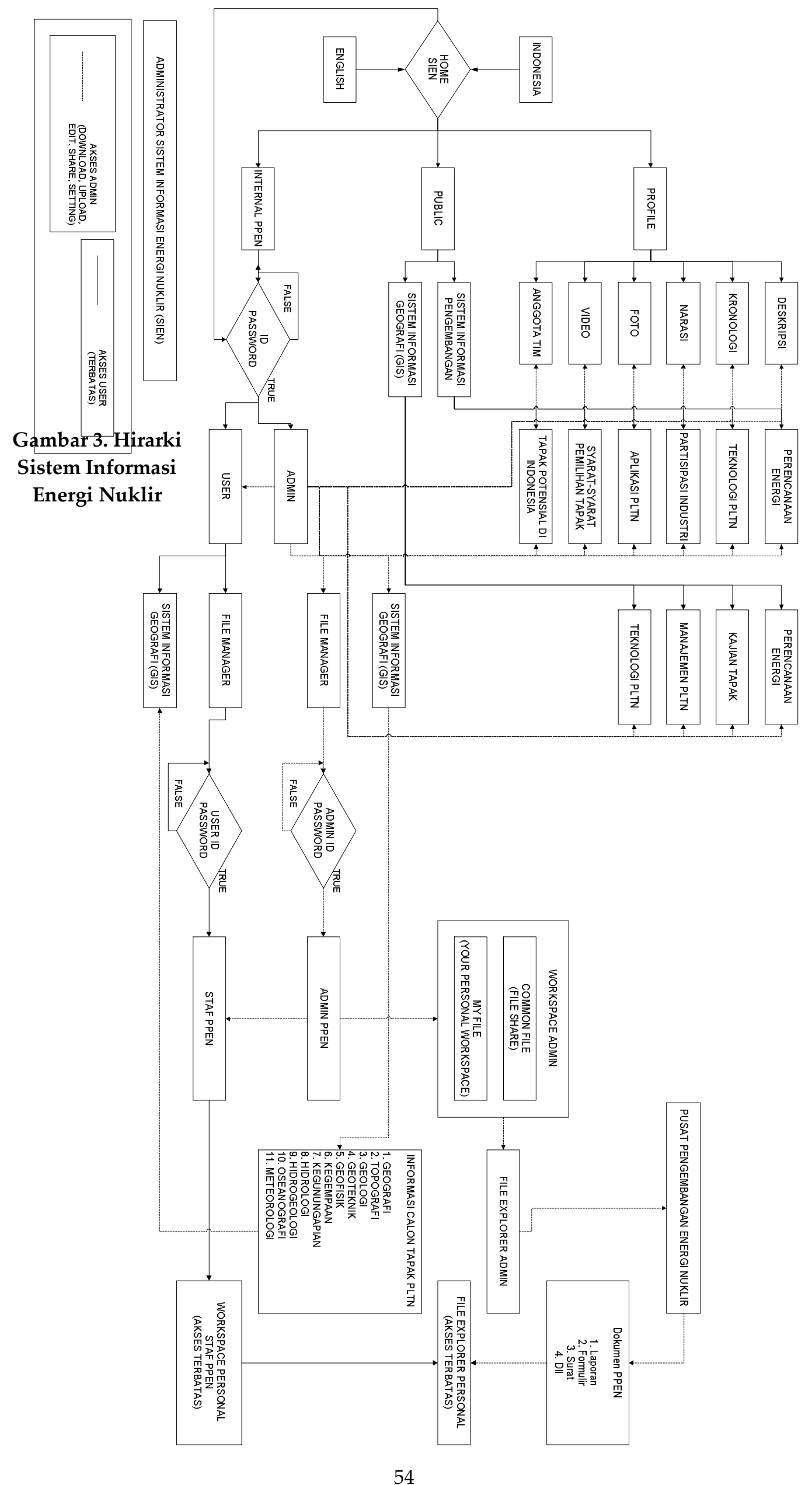




\section{KESIMPULAN}

Hasil penelitian ini adalah sebuah rancangan dasar Sistem Informasi Energi Nuklir (SIEN) yang nantinya akan mempermudah penerapan SIEN yang akan digunakan sebagai sistem pengelolaan hasil penelitian dan kegiatan PKSEN juga dapat digunakan sebagai media informasi bagi masyarakat.

Beberapa tahapan proses analisis dan perancangan SIEN yang telah dilakukan pada penelitian ini adalah: (i) analisis sistem organisasi, yang mengidentifikasikan seluruh aktivitas dan sumber daya organisasi PKSEN yang terkait dengan penerapan SIEN; (ii) analisis dan perancangan sistem informasi menggunakan analisis SWOT, dan mengidentifikasikan beberapa jenis perangkat yang dibutuhkan pada penerapan SIEN; (iii) analisis dan perancangan sistem perangkat lunak, yang menghasilkan hirarki SIEN; (iv) analisis dan perancangan sistem basis data, yang menggunakan sistem basis data terpusat dan pemilihan DBMS MySQL.

Analisis dan perancangan Sistem Informasi Energi Nuklir (SIEN) merupakan langkah awal untuk menerapkan dan membangun SIEN secara utuh dan terintegrasi, sehingga diharapkan kedepannya penelitian ini dapat dilanjutkan dengan melakukan pembangunan SIEN.

\section{DAFTAR PUSTAKA}

[1]. O'BRIEN JA, “Introduction to Information System 12th ed", McGraw-Hill Companies, Boston, 2005.

[2]. ELMASRI R, NAVATHE S B, "Fundamentals of Database Systems Sixth Edition", AddisonWesley, ISBN-13:978-0-136-08620-8, United States of America, 2011.

[3]. FALAHAH, WAWAN D, "ERP Menyelaraskan Teknologi Informasi dengan Strategi Bisnis", Informatika, Bandung, 2007

[4]. — http://teknologi.kompasiana.com/internet/2010/03/27/tantangan-implementasipengembangan-sistem-informasioperasional-dan-ti-dibawah-kepemimpinan-manajemen/, diakses pada 3 Maret 2014

[5]. — http://saifulrahman.lecture.ub.ac.id/files/2010/03/Tantangan-Manajemen.pdf, diakses pada 3 Maret 2012

[6]. SUHENDAR E, "Pemanfaatan Teknologi Informasi dalam Pembangunan Pertanian", Prosiding Seminar Nasional Informatika Pertanian Indonesia, Himpunan Informatika Pertanian Indonesia, Bandung, 21-22 Oktober 2011

[7]. MOENIR A S, "Kepemimpinan Kerja : Peranan Teknik dan Keberhasilannya", Bina Aksara, Jakarta, 1988

[8]. SHINDE S S, “Computer Network”, New Age International (P) Ltd., Publishers, 2009

[9]. WANG JIE, "Computer Network Security : Theory and Practice", Springer, 2009 